\title{
THE IMPACTS AND NON-IMPACTS ON UNIONS OF ENTERPRISE BARGAINING
}

\author{
DAVID PEETZ*
}

In analysing the impact of enterprise bargaining on unions, we need to distinguish the concepts of 'enterprise' and 'bargaining' and their separate implications for union power, and to distinguish and understand the relationship between individualisation and enterprise bargaining. Australian unions had several, interrelated motives for the shift to enterprise bargaining - their shift was the outcome of a willing but constrained choice in an environment where most other parties were pushing the logic of 'flexibility'. Some union objectives were achieved but other consequences arose, the shift to enterprise bargaining closing off the more comfortable union techniques, such as effective advocacy and servicing, formerly used to maintain membership. Unions saw the shift as a way to revive membership; many employers saw it as the opposite, and were the more successful in that regard, because of structural union problems at the workplace. The move from awards to collective bargaining removed the long-standing dependence of unions on arbitration, and was probably inevitable one way or another. This had the potential to make unions more responsive and active at the workplace and opened the door to methods of union revitalisation based around principles of organising. However, the move from multi-employer to single-enterprise exposed weaknesses where unions did not have the infrastructure to be already active and clearly undermined the union power, even if the relative position of some improved. Employers also utilised individualisation strategies but these were not dependent on a shift to bargaining, though the legislative framework enabling 'non-union' agreements facilitated individualisation.

THE SHIFT TO ENTERPRISE BARGAINING WAS A TRANSFORMATIVE moment in Australian industrial relations. The period since has also been characterised by upheavals within the union movement. It is easy to ascribe the latter

* David Peetz is Professor of Employment Relations and Human Resources at Griffith University. Address for correspondence: d.peetz@griffith.edu.au. The author wishes to thank Janis Bailey for her help on this project, Stephen Frenkel, Lynne Tacy and Georgina Murray for earlier assistance that enabled this to be written, and Heather Peetz for careful editing. 
to the former, so an aim of this paper is to disentangle the two and consider how much of the change in unions can be attributed to the shift to enterprise bargaining. It is organised as follows. I commence with an outline of the key elements of the historical backdrop to enterprise bargaining in Australia. Union motivations for the shift to enterprise bargaining are then discussed. I analyse trends in union membership under enterprise bargaining. I distinguish the concepts of 'enterprise' and 'bargaining' and their separate implications for union power. I also distinguish, and explain the relationship between, individualisation and enterprise bargaining. Finally I consider whether unions achieved their goals and whether alternatives were realistically available, with some mention of ongoing challenges. This article follows the discursive norm of referring to the system of single-employer bargaining that emerged in Australia as 'enterprise bargaining', despite the variety of forms it encompasses, including bargaining at the organisational, divisional or workplace level within an enterprise or public agency.

\section{The historical backdrop}

For the best part of a century prior to the shift, unions were heavily integrated into the award system. Awards were made as a result of tribunals settling disputes between unions and groups of employers (Gardner and Palmer, 1992), and the structures of unions and awards came to reflect each other (Gill and Griffin, 1981). Unions made strategic use of the arbitration and wage board systems and developed skills focused around advocacy in tribunals, often at the expense of (and sometimes actively discouraging) workplace union organisation. To varying degrees their structure resembled a comet, with a head or core of 'hot shops' that were populated by activist delegates and members, and a long tail of workplaces where unions had a presence but were not so active, sometimes having delegates that only functioned as post-boxes or not having any delegates at all. Unions varied substantially in the degree to which they developed workplace unionism or relied upon arbitration (Rimmer, 1989, 2004): some unions had a very large activist core, but others were mostly tail, being heavily reliant on arbitration. The award system actively encouraged compulsory unionism (Zappala, 1991) and so a lot of members were recruited into the union, especially into that tail, because they had to belong to keep the job. A common union wage strategy was to mobilise the activist hot shops to secure gains, and then use the award system to spread the gains through the tail. The system facilitated the development of weak workplace organisation through significant sections of the Australian union movement, as much union activity was focused at the award level and at arguing before tribunals (Crosby, 2005).

Union industrial disputation strategies also evolved to match the award system. Over the first three decades of the twentieth century, strikes that ended after negotiation accounted for approaching two thirds of working days lost, but they declined to just one fifth by the 1950s (Perry, 2005). Arbitration grew, and then 
receded as a means of settling disputes, as unions acculturated to how the arbitration system could be made to operate. They developed the use of short, unconditional strikes - that is, strikes that might last only a day or two, sometimes a few hours, that acted as a signalling device to employers, and to tribunals, to show that they were serious and that they could, if they wanted to, impose significant harm on the employer (Peetz, 2012). The issue in dispute would not be immediately resolved but the conciliation and arbitration system would swing into action and the underlying matter eventually resolved either by negotiation or arbitration. By the last couple of decades leading up to the Accord, these unconditional strikes, although short, accounted for roughly half of working days lost. So Australian unions embarked upon strike strategies that were very different to the much longer, sometimes drawn out disputes that characterised North America and, to a lesser extent, the UK; but they had them more often (Peetz, 2012).

Australian unions also relied upon their political connections with the Australian Labor Party. When Labor was in government at the state or federal level, unions would lobby it to obtain various benefits or concessions for their membership or for union activities or priorities. This culminated in the 1980s Accord between an incoming Labor government and the ACTU (Singleton, 1990). Initially a highly centralised mechanism for determining wage movements across the board, the Accord itself had a major impact on unions. Amongst other things, it led to centralisation of power within the union movement into the hands of the ACTU (Griffin, 1994; Briggs, 2002) and a reduction in real wages - though this was initially offset by reductions in inequality through improvements in the social wage such as the introduction of Medicare (Raskall and Urquhart, 1994 cited in Phillips, 1995) and by tax cuts. It also led to a further reduction in workplace activism beyond that already imposed by the logic of award reliance; though, as the first Australian Workplace Industrial Relations Survey (AWIRS) showed, workplaces in which unions which had good delegate structures could still be, and were, active in negotiating over non-wage matters (Morehead, Steele, Alexander, Stephen and Duffin, 1997). The Accord also gave unions unprecedented access to the 'corridors of power' (Singleton, 1990), though only within limits circumscribed by the Labor government's enthusiastic adoption of liberal market values, with unions in a constant contest with the bureaucrats, business and Ministers about the direction of some important aspects of policy. Thus unions' grand vision, of an Australian ship of state moving towards an adapted Nordic model of national training, industry development and incomes policies with activist yet coordinated unionism, floundered on the rocks of Treasury (Scott, 2000, 2006; Bray, Waring and Cooper, 2011).

\section{Motivations for the shift to enterprise bargaining}

It was through the Accord processes that the shift to enterprise bargaining occurred, and unlike any other union movement in the developed world, the 
Australian one actively pushed for that shift to decentralise bargaining(Katz, 1993; Briggs, 2001; Kelty, 2011). To understand the effects of enterprise bargaining on unions, including whether it achieved its goals, we also have to understand why Australian unions were so keen in the first place.

There were several reasons. First was disintegrating solidarity between strong and weak unions over wage restraint (Briggs, 2001). There was considerable pressure to 'let the dogs of the leash', to enable the more powerful unions in particular to obtain real wage increases. Union members were unhappy, not so much with the concept of the Accord - which was overwhelmingly endorsed in surveys (e.g. Morgan Gallup Polls, 1985) - but in how it was operating.

Second, there was strong dissatisfaction, particularly in the upper levels of the union movement, with the Australian Industrial Relations Commission (Briggs, 2001; Kelty, 2011). The Commission would not always deliver the outcomes that had been agreed between the unions and the government, particularly on matters such as award restructuring - seen as pivotal to improving productivity - and superannuation. Some may have been quietly happy about that in government, but not in the union movement.

Third was a desire to revive union membership, which had stagnated. Unions saw the Accord as encouraging free riding by non-union members. Unions negotiated wage increases and other improvements in living standards like national superannuation at the national level, but the benefits they negotiated accrued to non-members as much as members. People thought the gains were due to the decisions of the Arbitration Commission, or maybe even the government, they did not recognise the central role unions played in obtaining them. A shift to enterprise bargaining would make the source of wage gains visible and reduce free riding.

Fourth, there had been a slowdown in national productivity growth (ABS Cat No 5204.0), driven by the real wage reductions that had removed the incentive for employers to introduce labour-saving technology. Though pivotal to government concerns, this was not a major factor in union decision making at the time (except perhaps at the top). Many unions were still wedded to more coordinated, Nordic approaches to productivity improvement (Scott, 2006). Still, it became an important retrospective justification with, for example, the former ACTU secretary arguing that productivity was significantly higher in the twenty years after the move to enterprise bargaining than the twenty years before, 'not by a little bit, but by 60 per cent' (Kelty, 2011).

Fifth, there was political momentum emerging amongst employers for a shift to the enterprise level. The Business Council had published its policy documents with some favourable commissioned research that put the case for enterprise-based bargaining units (Business Council of Australia, 1989). The Coalition parties too, which once had defended arbitration from the barbaric nature of collective bargaining, were now pushing for a system that had the ability 
to circumvent unions at the workplace level (Dabscheck, 1990). While Labor was in government, the unions could have successfully resisted this pressure, were it not for the final factor: unions knew that one day a Coalition government would come to office. For a while they thought it might happen in 1990, and were almost certain it would happen in 1993. They wanted to put in place a system of enterprise bargaining that would be relatively friendly to unions, to pre-empt the actions of a Coalition government, and give themselves time to adjust.

The above views were not held in equal measure by all unions or their leaderships, but they were decisive at the ACTU and it could not have made the shift if it did not have the support of a majority of those unions that had significant influence.

\section{Enterprise bargaining and union membership}

What happened to union membership under enterprise bargaining? Figure 1 shows a century of union membership estimates, and Figure 2 shows contemporaneous estimates of union density (membership as a proportion of all employees). Until 1992 the Statistician undertook a census of trade unions, the source for membership data over most of this period. It was discontinued because of questions about its reliability and cost. For most of the time it did not distinguish between financial and non-financial members, and so total membership is shown as the grey line in Figure 1. From 1976 to 1988 the ABS ran an occasional survey of trade union membership (shown by the dotted black line); from 1990 onwards this became an annual data collection. For the annual data from 1990 the data presented in Figures 1 and 2 are based on trend estimates (shown by the continuous black line), as are the text and table that follow. This is because the annual ABS data on union membership are derived from surveys, and therefore subject to sampling error. This makes them variable from year to year simply by chance, and the smaller the group (such as an sectoral or occupational group), the more erratic and hard to read movements in original data become. The trending technique is one deployed by the ABS: a seven-term Henderson weighted moving average. Further details on the technical aspects are in an earlier publication (Peetz, 2005). Trend analysis has not been applied to pre-1990 estimates either because they were not regular or were based on a census and therefore not subject to sampling error. The discrepancies between the survey and census are also explained elsewhere (Peetz, 1998). All numbers quoted here are trend estimates.

Figures 1 and 2 show that, after the long period of sustained growth in membership (the dashed line) through the twentieth century, and a level of union density that moved around mostly in a range from the high 40s to the mid 50s, membership stagnated in the 1980s and density fell. Then through the 1990s, after the introduction of enterprise bargaining both membership and density fell. In the 2000s, after unions started to move slowly towards something resembling 
an organising approach, membership more or less stabilised, dropped under Work Choices, then grew again after the latter was repealed. The decline of density slowed in the 2000s, accelerated again during Work Choices, but it appears to have nearly stabilised over the past three years.

Figure 1. Trade union membership, 1910-2010, Australia

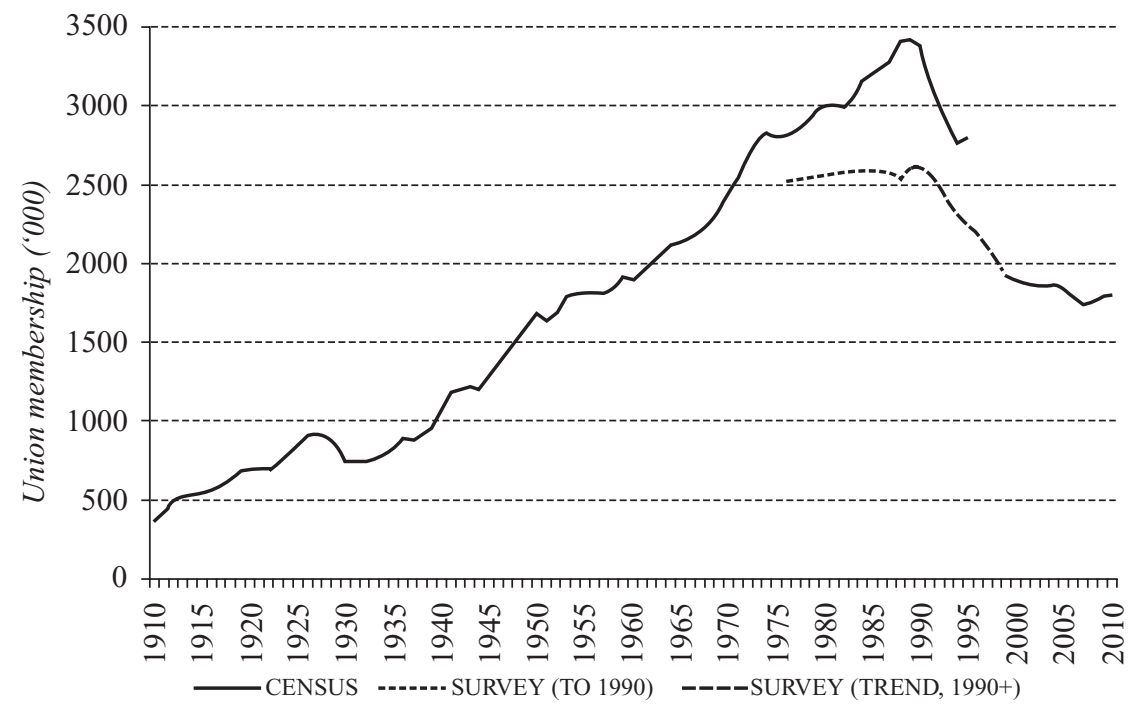

Figure 2. Union density, 1910-2010, Australia

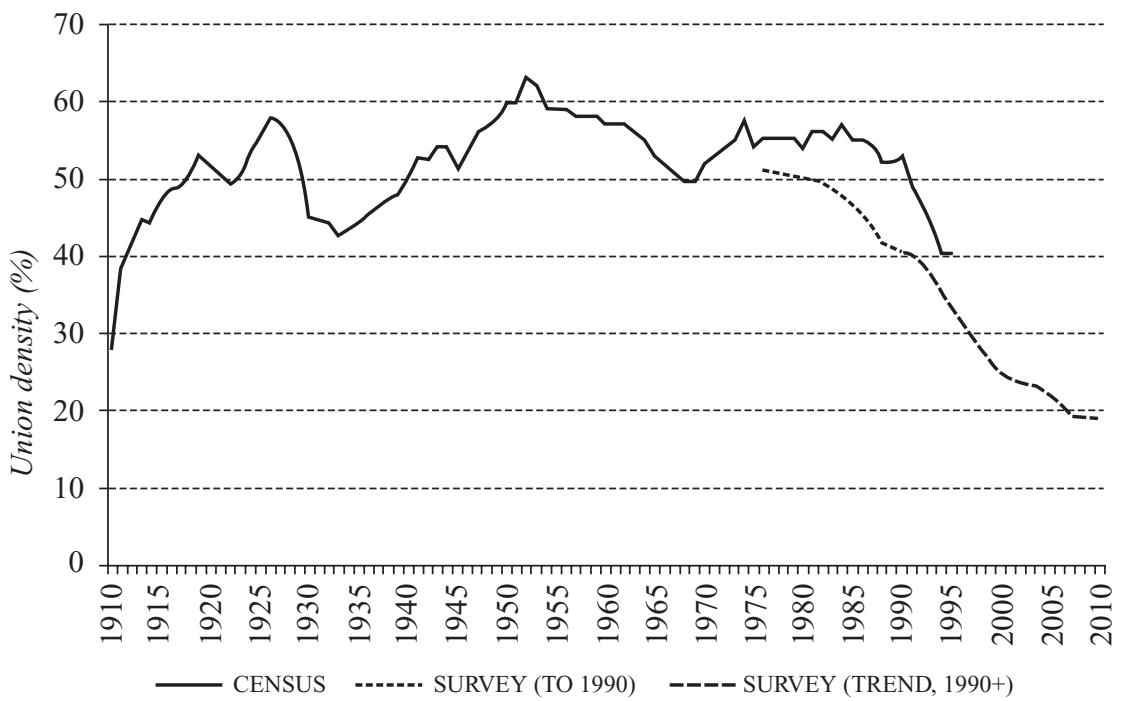


Table 1 shows trend density in 1990, 2000 and 2010, by gender, hours of work, sector and employment status. Density dropped by considerably more among men than among women from 1990, when there had been a 10-percentage point density gap in favour of men. This was due partly to the fact that compulsory unionism was more common in male jobs and, as it collapsed, men were disproportionately less likely to remain in unions. This does not account for all of the discrepancy, however, as compulsory unionism had all but disappeared by 2000 but there was still a small gender gap (3.6 percentage points) in favour of men. Different strategies by unions with different gender compositions probably also had an effect. For example, 'health and welfare associate professionals' (72 per cent female) showed an increase in density from 46 per cent in 1999 to 49 per cent in 2007 , and 'health professionals' (78 per cent female) showed stability (at 43 per cent) from 1999 through 2004, before falling under Work Choices. By 2010 women had, for the first time, a slightly higher rate of union density than men. In the last few years, trend density has been fairly stable for women but continued to decline for men.

Density dropped by more than half over two decades among full-time workers, but by less than half among part-time workers, who are predominantly female. Notably, though, density fell by 64 per cent amongst casual employees, compared to 47 per cent amongst permanent employees, suggesting particular

Table 1. Trend density by gender, hours, sector and employment status, 1990, 2000, 2010, Australia

\begin{tabular}{lrrr}
\hline & $\mathbf{1 9 9 0}$ & $\mathbf{2 0 0 0}$ & $\mathbf{2 0 1 0}$ \\
$\begin{array}{l}\text { Gender } \\
\text { Males }\end{array}$ & $44.7 \%$ & $26.5 \%$ & $18.7 \%$ \\
$\quad \begin{array}{l}\text { Females } \\
\text { Hours }\end{array}$ & $34.7 \%$ & $22.9 \%$ & $18.8 \%$ \\
$\quad \begin{array}{l}\text { Full-time } \\
\quad \text { Part-time }\end{array}$ & $44.7 \%$ & $27.9 \%$ & $20.6 \%$ \\
$\begin{array}{l}\text { Sector } \\
\quad \text { Public }\end{array}$ & $17.3 \%$ & $14.3 \%$ \\
$\quad$ Private & $25.2 \%$ & & \\
Employment Status & & $48.2 \%$ & $43.5 \%$ \\
$\quad$ Permanent & $67.0 \%$ & $19.2 \%$ & $13.6 \%$ \\
$\quad$ Casual & $30.5 \%$ & $30.5 \%$ & $24.1 \%$ \\
All employees & $45.9 \%$ & $9.5 \%$ & $6.8 \%$ \\
\hline
\end{tabular}

Source: Calculated from ABS 6310.0. See text for methodology. 
difficulties for unions amongst casuals. It fell by more than half in the private sector, but by less than half in the public sector.

We cannot, though, simply attribute the membership decline, even principally, to enterprise bargaining per se. Over the half-decade leading up to the second AWIRS in 1995-96, the workplaces where unions suffered the most severe drops in membership, or where the workplaces became deunionised altogether, were those where unions had previously had no union delegates, or where the delegates had been inactive in bargaining (Peetz, 1998, Ch. 6). In other words, unions lost members in the workplaces where unions were not organised at workplace level to cope with enterprise bargaining. In addition, as discussed below, we should not confuse enterprise bargaining with individualisation. Antagonism towards unions by a number of large employers and a range of governments led to practices, interventions and regulation that made life difficult for unions. There was also structural change in the labour market, from industries, occupations, sectors and job types traditionally with high union density to those with low union density, though this was not as significant in the enterprise bargaining period as it had been in the 1980s. The key thing with enterprise bargaining was the way in which it interacted with weak workplace unionism, as discussed below.

\section{Union power and the grammar of the shift to enterprise bargaining}

There are two distinct conceptual elements in the shift to enterprise bargaining. The first, relating to the noun and verb bargaining, is the shift from arbitration to collective bargaining. The second, related to the adjective enterprise, is the shift from multi-employer (at the time, national level) determination of pay and conditions to single-employer pay determination. In the grammar of the shift to enterprise bargaining, it is the adjective that created more problems.

These two elements had quite distinct manifestations. For example, the move from arbitration to collective bargaining brought Australia into line with most other developed countries. By contrast, the move from multi-employer to single-employer pay determination moved Australia from one set of relatively centralised countries to another set of relatively decentralised countries - some national systems also moved in this direction, but others did not. To understand the effect on union power, we should not only look at that common proxy for union power, union density, but also consider how 'enterprise' and 'bargaining' separately affected union power.

It is clear that, just as arbitration had differential effects on unions and workers, so too the shift to bargaining advantaged some unions and disadvantaged others. Evidence suggests wage relativities were more compressed in Australia under arbitration than in the US and probably the UK. During the 1930s depression, the relative wages of unskilled workers were better protected in Australia. 
Progress towards equal pay was quicker in Australia than in Britain or several other countries (Brown, Hayles, Hughes and Rowe, 1978; Norris, 1980; Rowe, 1982; Norris, 1983b). When enterprise bargaining came in, traditional industry transmission mechanisms under awards largely broke down. Settlements in one industry did not transmit strongly to other industries. For example, construction and transport showed higher increases than other industries for some time, while metals manufacturing led wages growth in the rest of the private sector, with no indications other industries would catch up (e.g. Department of Workplace Relations and Small Business, 1998). Within industries there was also substantial variance in outcomes. Overall dispersion in agreement wage outcomes increased noticeably after the first round of bargaining in 1992, though it peaked in 1996 (ibid.). The shift to bargaining thus probably made unions more powerful in industries where they had been constrained by arbitration. (For some of these unions, the arbitration commission and its successors and offshoots was seen as a 'bosses' court'.) But equally it made unions less powerful in those industries and workplaces where they had been bolstered by arbitration (and tribunals were slammed as providing 'union privilege').

While the shift to bargaining affected relativities between unions, its net impact on aggregate union power was probably smaller. This is because the research literature suggests arbitration had little effect on unions' overall position. While, according to Norris (1983a), tribunals had on occasions acted independently and distinctly influenced the timing of wage increases, the empirical evidence indicated tribunals were mainly an agent through which 'market forces' were translated into wage increases. Explanations of wage inflation which excluded the Commission fitted the facts 'tolerably well'; and variables widely used in non-institutional explanations of wages growth were the same as those used to explain institutionally-determined award wages growth (Norris 1983a). To maintain legitimacy, over the long run tribunals needed to produce outcomes broadly in line with what the parties would have otherwise generated (Dabscheck, 1980; Romeyn, 1980).

One benefit from bargaining was the potential impact on employee power to influence change. Data from the mid 1990s showed workers evenly split on whether they were better or worse off as a result of workplace change, employees under agreements were much more likely to say they were better off (41 per cent) than worse off (21 per cent) as a result of workplace bargaining (Department of Industrial Relations, 1995). Absent of bargaining, workers were less likely to be compensated for work intensification or change (Department of Industrial Relations, 1995).

On the other hand, the shift from multi-employer wage determination to single-employer determination moved unions from wage determination at levels where potential power was relatively high to a level where, for the majority, power was at its weakest. Unions commonly aggregate at an industry or national 
level to increase their bargaining power (Commons, 1909). Although there may be exceptions for individual unions (Katz, 1993), the move to the enterprise level, on average, reduced the power of unions. The move also relocated union action to a level where the potential for co-ordination in pursuit of movementwide social objectives was low. It is one thing to negotiate with a national government about introducing a national superannuation system, or to make a case at a national level to a tribunal about equal pay. It is another to try to achieve those things on an employer-by-employer basis.

Overall, the aggregate power effects on unions of the shift to enterprise bargaining came mainly from the enterprise, rather than from the bargaining, part of the concept. However, shifts in relative power between unions also arose from bargaining's replacement of arbitration.

\section{The enterprise, bargaining and individualisation}

It is important to distinguish the shift to enterprise bargaining from the shift to individualisation. Elsewhere the shift to individual contracting and hence de-unionisation in employer and government strategies has been analysed. Such strategies started amongst some employers and then employer bodies in the mid 1980s and characterised most government jurisdictions at stages during the 1990s. This shift was a core factor behind the decline in union membership and density at the time and subsequently. While not entirely independent of the shift to enterprise bargaining, individual contracting is something that can and did exist in its own right; it was neither dependent on the shift to enterprise bargaining to occur nor a logical corollary of the shift to enterprise bargaining (Peetz, 1998). The big employer-driven disputes of the mid 1980s that presaged the broader shift, in SEQEB, Hamersley Iron, Mudginberri and the like (Guille, 1985; Coghill, 1987; Creighton, 1987), happened within the context of a highly centralised system. In a number of its major sites CRA (later Rio Tinto) removed most workers from awards, independent of the wage system (Hearn Mackinnon, 2007). The Coalition's radical and ill-fated 'Jobsback!' industrial relations policy of 1992 was modelled on the New Zealand Employment Contracts Act of 1991, which in effect took New Zealand straight from awards to individual contracts with no transitional enterprise bargaining (Harbridge and Walsh, 1989; Dannin, 1997). Australia no more required enterprise bargaining as a transition to individual contracts than did New Zealand. It is more accurate to see the shift to enterprise bargaining as an attempt, (somewhat unsuccessful) to pre-empt institutionalised individual contracting.

There were, however, some important interactions between de-unionisation and enterprise bargaining. A peculiarity of the shift to enterprise bargaining is that it did not increase the number of workplaces where bargaining took place. The first AWIRS, undertaken in 1989-90, categorised 27 per cent of workplaces 
with 20 or more employees as engaging in 'workplace bargaining' or 'delegate negotiations' over any issue. The second AWIRS, undertaken nearly six years later, found that the proportion had fallen to 19 per cent (Morehead et al., 1997). Other early surveys indicated the proportion of workplaces where matters were negotiated had likewise changed very little between 1992 and 1994 (Short, Preston and Peetz, 1993; Department of Industrial Relations, 1995). More recent data from Workplace Research Centre surveys suggest the number of bargaining workplaces has fallen further since 1995 (Considine and Buchanan, 2007).

How could it be that workplace bargaining declined in the early 1990s? After all, the number of employees covered by federally registered enterprise agreements grew through the early 1990s, from a base of virtually zero. The key is to recognise that bargaining already existed at that level, in workplaces where unions were well organised. However, especially because of the Accord, bargaining often did not occur over wages. Employers normally initiated workplace-level bargaining (Morehead et al., 1997), and those who had not bargained in the past would not be forced to the table by safety net award increases of merely $\$ 8$ per week for each of three years.

So, in the 1990s, workplace collective bargaining was undermined by weak infrastructure and weak incentives for bargaining. At the heart of infrastructural inadequacies were the declining availability of unions and union delegates, and the underdeveloped bargaining skills of the delegates - nearly half of senior union delegates in AWIRS95 reported that their bargaining skills were 'really not good enough' or non-existent (Morehead et al., 1997). Meanwhile management became less willing to negotiate with unions anyway. The problem was not that enterprise bargaining per se undermined unionism. It was that weak workplace unionism undermined union collective wage bargaining. This ultimately further eroded workplace unionism and created a negative feedback loop.

For unions, if they could successfully engage in collective bargaining, the empowerment of members had the potential to boost union membership. The sometimes forgotten principles of organising, derived from many decades of experience, told unions that successful negotiation of claims that actively involved members in their design and prosecution would motivate workers to become more active in the union, demonstrate increased power and attract nonmembers to join a body they could see had the power to make a difference (Crosby, 2005). But how successful their engagement in collective bargaining would be was clouded by a system that reduced average union power by shifting the locus of wage determination downwards.

That said there is one important mechanism by which enterprise bargaining clearly facilitated union exclusion: the unique way in which Australian enterprise bargaining law allows non-union agreement-making. In the rest of the world, collective bargaining is union bargaining. That is for good reasons: non-unionised employees cannot be expected to have the resources to effectively 
bargain collectively with employers. A process whereby an employer submits a proposed agreement to employees for a vote cannot accurately be characterised as collective bargaining, even if the outcome is labelled a 'collective agreement'. However, it does provide another mechanism by which employers have circumvented unions. The original, 1991, conception of the shift to enterprise bargaining, at least from union's point of view, had no room for non-union collective agreements. Employers pushed for non-union bargaining and in the end the government responded with enterprise flexibility agreements (EFAs). The ACTU leadership was initially happy to acquiesce to this because they did not believe these would achieve any traction, given the limitations of the conciliation and arbitration power in s51 of the constitution (until a government adviser conceived of using the corporations power in s51 to underpin EFAs, an idea which eventually formed the constitutional basis for Work Choices). Non-union 'collective bargaining' was of limited consequence while Australian Workplace Agreements (AWAs) were also available to employers as the latter became the principal means by which employers achieved exclusion. With the demise of AWAs under the Fair Work Act, it appears that there has been a surge in non-union agreement-making (Gahan, this volume).

\section{Did unions achieve their goals?}

There were a number of intended and unintended consequences for union. Some goals were certainly achieved. Enterprise bargaining improved the relative position of stronger unions, at least compared to the weaker unions. Almost by definition, it overcame the perceived problem that had emerged in the national level relationship between unions and the tribunal, by more or less making that relationship redundant. After a period of real wage decline, the move to enterprise bargaining saw an increase in real wages. It also saw a small increase, over at least the Accord period of enterprise bargaining, in the share of wages relative to profits. After the Coalition government came in, that started to turn around, and the share of profits relative to wages increased substantially, eventually to record levels, and has remained near those levels under the Fair Work Act's version of enterprise bargaining (ABS Cat No 5204.0, 5206.0).

It cannot be said that enterprise bargaining led to a revival of union membership: membership fell markedly in the decade after it was introduced, though as mentioned it does not follow that enterprise bargaining was the principal villain. Still, the shift to enterprise bargaining also failed to deal with the problem of free riding. In a world with no free riding and all unionists covered by collective agreements, union density and collective agreement coverage would be the same. To the extent that collective agreement coverage exceeds union density, there is free riding in place. In 2010, while 43 per cent of employees were covered by collective agreements, only 19 per cent were union members. 
Over the preceding decade collective bargaining coverage had grown (from 37 per cent) while union membership had fallen (from 25 per cent). Between 2008 and 2010 most of the increase in collective agreement coverage (from 40 to 43 per cent) was probably due to the growth of non-union agreements after the end of AWAs, but over the rest of that period, it seems clear free riding was both substantial - much greater than could be explained by nonunion agreements - and gradually increasing. It is also possible that free riding is greater than that gap shows, because some union members may be unable to negotiate agreements, especially in smaller workplaces.

The shift also gave unions almost six years of experience with enterprise bargaining before a national Coalition government came in and introduced its own version of decentralised wage determination. Whether that helped is difficult to confirm, but Australian unions appear in a stronger position than their counterparts in New Zealand, where no transition occurred. Despite similar levels of aggregate union density, only 9 per cent of private sector employees there are covered by collective agreements (Foster, Rasmussen, Murrie and Laird, 2011).

With real wages starting to grow again, national labour productivity also resumed a higher growth path. However, elsewhere in this volume, Hancock has shown no ongoing productivity impact arising from enterprise bargaining. In 2011, twenty years after the shift to bargaining, national productivity (GDP per hour worked) was 38 per cent higher than when the system had commenced - but on the other hand, over the twenty years preceding enterprise bargaining, it had already grown by 45 per cent between 1971 and 1991 (ABS Cat Nos 5204.0, 5206.0).

Overall, while some union objectives were achieved, they were probably not the most important ones for unions as a movement.

What else happened? Some survey data suggested enterprise bargaining led to improved relations between management and unions, relative to workplaces without enterprise bargaining (Department of Industrial Relations, 1995). Union dispute management strategies changed, though not radically. Reliance on the tribunals to end disputes reduced, but it was not because more strikes were directly ended by negotiation. Unions just made greater relative use of unconditional strikes, though overall strike numbers and working days lost declined substantially. Disputes related to a broader range of issues than just wages. They eventually became slightly longer, but have never approached the length of strikes in North America or Britain (Peetz, 2012).

Beyond this, though, enterprise bargaining has been very demanding for unions. It leads to the heavy use of union resources and time. This redirection of effort reduces unions' capacity to engage in industry and national level and movement-wide issues, while institutional barriers are greater. Adjustments have varied. Some unions have sought to maintain central control of bargaining strategies. Some have dispersed resources and capabilities to lower levels and 
to the workplace. Some have made internal structural changes (for example the Community and Public Sector Union shifted from a state-based to bargainingunit based national structure). At the start of the enterprise bargaining period many unions also went through one of the largest structural changes seen in Australian union history: the amalgamation program of the early 1990s (Griffin, 2005). It had some pluses and minuses for unions, some of which probably would not have survived on their own, but certainly occupied much union attention while they also sought to come to grips with the new wage system.

More importantly, many unions, or at least some branches of many unions, subsequently began to adopt organising approaches to relations with their members, in place of the servicing approach that was more characteristic of unions under the award system. It is doubtful that most unions could have shifted to an organising approach without the move to bargaining, as the logic of awards and tribunals so shaped the actions of unions. While some unions, such as in coal mining, had been able to pursue organising approaches within a tribunal framework - in the case of coal, a specialist tribunal had to be established to accommodate the circumstances bargaining in that industry created (Romeyn, 1982) - for most unions the inertia and 'institutional sclerosis' (Pocock, 1998) that emerged within the award-based framework would have likely prevented major internal change until the last union building had been sold off. Whether the shift to enterprise bargaining was so crucial in this move to organising is another matter.

\section{Challenges and alternatives}

Was there an alternative? The external pressures in support of a move from arbitration were growing, as employer demands for flexibility spread globally (Streeck, 1987). Could unions, though, have successfully abandoned their reliance on arbitration, and its deadening effect on workplace activism, without also abandoning the capacity for multi-employer wage determination? Such an approach would have required the development of more widespread workplace activist infrastructure, while maintaining the capacity for national level bargaining (along the lines of the Nordic countries admired in late 1980s, though some were themselves subsequently subjected to decentralising forces (Katz, 1993)). Australian unions had developed in part a vision of a Nordiclike system, but they were unable to overcome the neoclassical narrative from bureaucrats, so any move would have lacked institutional support. It would not have been easy, under the then-dominant constitutional framework based around the conciliation and arbitration power, to find a basis for generalising bargained wages and conditions. It would, however, have been simple to permit multiemployer bargaining, as all that came to prevent it was a provision created for the Industrial Relations Reform Act - itself negotiated through a working party of union and government representatives in the bipartite spirit of the Accord, 
and quite unlike the way the Fair Work Act was developed. But that option was simply not part of the discourse of the period.

A number of challenges remain for unions in a world of enterprise bargaining. One is presented by the emergence of legal apparatus for non-union agreement making, mentioned earlier. Another is the tension between having a broad orientation to movement and societal goals and values, including equity - looking upward and outward - and the necessity to resource the workplace looking downward and within. In the enterprise bargaining world, the presence of democratic practices in unions is especially necessary, as decision making must centre on the workplace if members are to feel that membership is worthwhile. Resourcing the workplace requires scarce funds to be devoted to extensive investment in training and follow-up of trained delegates and members. On the other hand, coordination of union practices is much harder when decisions are workplace-based, unless those people from the workplace are also central in shaping the overall strategies of the union.

Unions' shift to enterprise bargaining was the outcome of a willing but constrained choice in an environment where most other parties were pushing the logic of 'flexibility'. The move from awards to collective bargaining removed the long-standing dependence of unions on arbitration, and was probably inevitable one way or another. This had the potential to make unions more responsive to their membership, more active at the workplace. That was part of its intention, part of that idea of developing a union-friendly system of bargaining. Whether the move from multi-employer to enterprise was also inevitable is another matter, but it has more clearly undermined the power of unions. The move to enterprise exposed their weaknesses where they did not have the infrastructure to be already active and relocated wage determination to a level that shifted the overall balance of power against unions, even if some were relatively advantaged. Unions saw it as a way to revive membership; many employers saw it as the opposite, and were the more successful in that regard, because of structural union problems at the workplace. Some union goals were achieved, but the shift to enterprise bargaining closed off the more comfortable ways unions commonly sought to maintain membership, through effective advocacy and servicing, and instead opened the door to methods of union revitalisation based around principles of organising. Whether they can successfully implement these in the face of a structurally more hostile environment is not so clear.

\section{References}

Bray, M, Waring, P \& Cooper, R (2011) Employment Relations: Theory and Practice, McGraw-Hill, Sydney.

Briggs, C (2001) 'Australian exceptionalism: the role of trade unions in the emergence of enterprise bargaining' Journal of Industrial Relations, 43 (1) pp. 27-43. 
Briggs, C (2002) 'The paradox of ACTU hegemony' Labour and Industry, 12 (3) pp. 77-102. Brown, W, Hayles, J, Hughes, B \& Rowe, L (1978) 'How far does Arbitration Constrain Australia's Labour Market?' Australian Bulletin of Labour, 4 (1) pp. 31-39.

Business Council of Australia (1989) Enterprise-based bargaining units: A better way of working. Part 1, BCA, Melbourne.

Coghill, K (1987) 'Regrouping to win hearts and minds'. in K Coghill. The New Right's Australian Fantasy. Penguin, Ringwood, pp.116-144.

Commons, J R (1909) 'American Shoemakers, 1648- 1895: A Sketch of Industrial Evolution' Quarterly Journal of Economics, 24 pp. 39-81.

Considine, G \& Buchanan, J (2007) Workplace Industrial Relations on the Eve of Work Choices: A report on a survey of employers in Queensland, NSW and Victoria, Workplace Research Centre, University of Sydney, Sydney.

Creighton, B (1987) 'Trade Unions, the Law and the New Right'. in K Coghill. The New Right's Australian Fantasy. Penguin, Melbourne, pp. 74-92.

Crosby, M (2005) Power at work: Rebuilding the Australian union movement, Federation Press, Sydney.

Dabscheck, B (1980) 'The Australian System of Industrial Relations: An Analytical Model' Journal of Industrial Relations, 22 (2) pp. 223-52.

Dabscheck, B (1990) 'Enterprise Bargaining: A New Province for Law and Order?' Australian Quarterly, 62 (3) pp. 240-255.

Dannin, E (1997) Working Free: The origins and impact of New Zealand's Employment Contracts Act, Auckland University Press, Auckland.

Department of Industrial Relations (1995) Enterprise Bargaining in Australia: 1994 Annual Report, AGPS, Canberra.

Department of Workplace Relations and Small Business (1998). Wage Trends in Enterprise Bargaining, DWRSB, Canberra.

Foster, B, Rasmussen, E, Murrie, J \& Laird, I (2011) 'Supportive legislation, unsupportive employers and collective bargaining in New Zealand' Relations Industrielles, 66 (2) pp. 192-212.

Gardner, M \& Palmer, G (1992) Employment Relations: Industrial Relations and Human Resource Management, Macmillan, Melbourne.

Gill, H \& Griffin, V (1981) 'The Fetish of Order: Reform in Australian Union Structure' Journal of Industrial Relations, 23 (3) pp. 362-382.

Griffin, G (1994) 'The authority of the ACTU' Economic and Labour Relations Review, 5 (1) pp. 81-103.

Griffin, G (2005) 'Australia: Top-down strategic restructuring'. in J Waddington. Restructuring Representation: The Merger Process and Trade Union Structural Development in Ten Countries. PIE-Peter Lang, Brussels, pp.45-66.

Guille, H (1985) 'Industrial Relations in Queensland' Journal of Industrial Relations, 27 (3) pp. 383-96.

Harbridge, R \& Walsh, P (1989) 'Restructuring Industrial Relations in New Zealand 1984-1988' Labour and Industry, 2 (1) pp. 60-84.

Hearn Mackinnon, B (2007) Behind Work Choices: How one Company Changed Australia's Industrial Relations, Heidelberg Press, Melbourne.

Katz, H C (1993) 'The Decentralisation of Collective Bargaining: A Literature Review and Theoretical Analysis' Industrial and Labor Relations Review, 47 (1) pp. 3-22.

Kelty, W (2011) 'The introduction of enterprise bargaining - a retrospective: Opening 
address'. Enterprise Bargaining in Australia, 1991-2011, Workshop, Melbourne, Melbourne Law School.

Morehead, A, Steele, M, Alexander, M J, Stephen, K \& Duffin, L (1997) Changes at Work: The 1995 Australian Workplace Industrial Relations Survey, Longman, South Melbourne.

Morgan Gallup Polls (1985) Survey of Trade Unionists Attitudes to the Accord. unpublished report to Department of Employment and Industrial Relations, Sydney.

Norris, K (1980) 'Compulsory Arbitration and the Wage Structure in Australia' Journal of Industrial Relations, 22 (3) pp. 249-263.

Norris, K (1983a) Economics of Australian Labour Markets, Longman Cheshire, Sydney.

Norris, K (1983b) 'Market versus Institutional Issues'. Australian Wage Determination Conference, Sydney, Industrial Relations Research Centre, University of New South Wales.

Peetz, D (1998) Unions in a Contrary World: The future of the Australian trade union movement, Cambridge University Press, Cambridge.

Peetz, D (2005) 'Trend analysis of union membership' Australian Journal of Labour Economics, 8 (1) pp. 1-24.

Peetz, D (2012) 'Industrial conflict with awards, choices and fairness'. in A Forsyth \& B Creighton. Rediscovering Collective Bargaining: Australia's Fair Work Act in International Perspective. Routledge, New York, pp.159-181.

Perry, L J (2005) 'A Long-Term Perspective on Industrial Disputes in Australia: 1913-2003' Economic Papers 24 (3) pp. 263-279.

Phillips, P (1995) 'Evaluating the Accord(s): A Comparative Canadian Perspective' Journal of Industrial Relations, 37 (4) pp. 524-542.

Pocock, B (1998) 'Institutional sclerosis: Prospects for trade union transformation' Labour \& Industry, 9 (1) pp. 17-33.

Raskall, P \& Urquhart, R (1994) Inequality, Living Standards and the Social Wage During the 1980s. Study of Social and Economic Inequalities Monograph No 3, Social Policy Research Centre/Centre for Applied Economic Research, University of New South Wales, Sydney.

Rimmer, M (1989) 'Work Place Unionism'. in W Ford \& D Plowman. Australian Unions: An Industrial Relations Perspective. Macmillan, Melbourne, pp. 122-144.

Rimmer, M (2004) 'Unions and Arbitration'. in J Isaac \& S Macintyre. The New Province for Law and Order. Cambridge University Press, Melbourne, pp. 275-315.

Romeyn, J R (1980) 'Towards a Motivational Theory of Arbitration in Australia' Journal of Industrial Relations, 22 (2) pp. 181-195.

Romeyn, J.R., 1982. Centralised and Specialist Tribunals: The Influence of Structure on Arbitral Decision-making in Australia. Industrial Relations Research Centre, University of New South Wales, Sydney.

Rowe, L (1982) 'Reward, Force or Compromise: Egalitarian Wage Structure Under Bargaining and Arbitration' Journal of Industrial Relations, 24 (2) pp. 245-265.

Scott, A (2000) Running on Empty: 'Modernising' the British and Australian Labour Parties, Pluto, Sydney.

Scott, A (2006) 'Social democracy in northern Europe: Its relevance for Australia' Australian Review of Public Affairs, 7 (1) pp. 1-17.

Short, M, Preston, A \& Peetz, D (1993) The Spread and Impact of Bargaining: Evidence from the Workplace Bargaining Research Project, Department of Industrial Relations/ AGPS, Canberra. 
Singleton, G (1990) The Accord and the Australian Labour Movement, Melbourne University Press, Melbourne.

Streeck, W (1987) 'The Uncertainties of Management and the Management of Uncertainty' Work, Employment and Society, 1 (2) pp. 281-308.

Zappala, G (1991) Mapping the extent of compulsory unionism in Australia. ACIRRT

Working Paper No 18, University of Sydney, Sydney. 
Reproduced with permission of the copyright owner. Further reproduction prohibited without permission. 